Educational and Psychological Studies Faculty of Education Journal Zagazig University

Vol. (36) No. (113), Part(2), October 2021

\title{
The Effect of the Radiant Thinking Strategy Based on Metacognition Theory on Smart Thinking (Case Study)
}

\author{
Asmaa.M.Abdullah \\ Al Azhar observatory, Cairo \\ asmaaabdalahazhar@gmail.com
}

\author{
Mohammad Hassan \\ ((Method\& Instruction department, \\ Faculty of Education \\ /Zagazig University) \\ mohammadhassan@yahoo.com
}

\author{
Michael Abdel Masseeh \\ (Method\& Instruction department, \\ Faculty of Education/Zagazig \\ University) \\ michaelawad@yahoo.com
}

\begin{abstract}
:
This paper handles teaching English as a process to learners who study English as a foreign language. It explores the radiant thinking strategy with its mapping techniques when applied to the skill of smart thinking on written English. And, the flexibility of using any of the four techniques of mapping is approved. Also, the combination between more than one map and diagram is valid; the research uses mind maps, concept maps, conceptual diagram, and visual metaphor as techniques in the Radiant Thinking Strategy. The research is also planned to make
\end{abstract}


use of the metacognition philosophy for planning to the strategy, and to the learning hour. Moreover, metacognition is used here for assessing the process of retention through post and post- post tests, and to evaluate the processes of teaching and learning. The new issue in such a research is the uses of the "case study methodology" to observe even a change in a sub skill while both the processes of teaching and learning happen.

Keywords: Metacognition; Radint Thinking; Case Study; English; Smart Thinking

\section{أثر إستراتيجية التفكير المتشعب المستندة على نظرية ما وراء المعرفة في تنمية مهارات التفكير الذكي}

(دراسة حالة)

\section{الملخص العربي}

تستكثف هذه الورقة البحثية إستراتيجية التفكير المتشعب بتقنيات رسم

الخرائط عند تطبيقها على مهارات التفكير الذكي الثلاث أثناء الترجمة من اللغة

الإنجليزية إلى اللغة العربية. ولتحقيق الهدف من الدراسة وهو تنمية مهارات التفكير

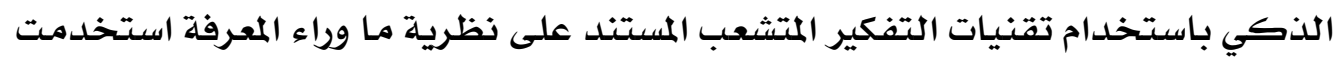

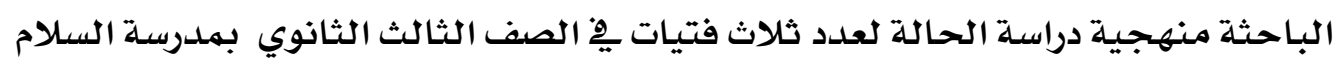

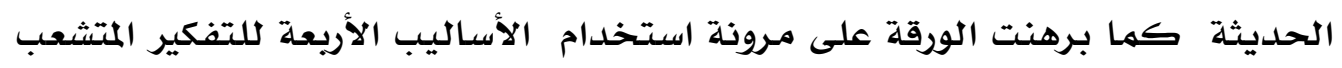

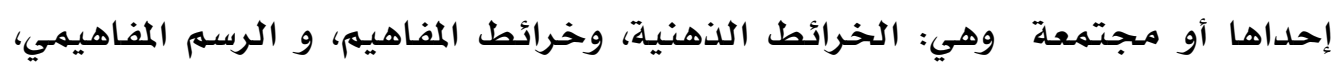

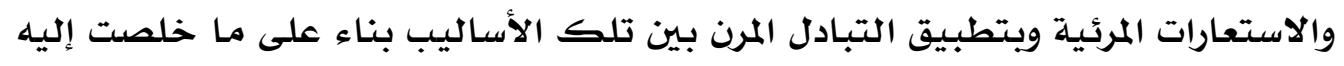


Educational and Psychological Studies Faculty of Education Journal Zagazig University

Vol. (36) No. (113), Part(2), October 2021

رسائل سـابقة تم الجمـع بين أكثر من خريطة وفقًا لحالة الكلمات والاستخدام المرن لها. وقد استخدمت الباحثة الأدوات التالية للدراسدة: تحليل الأخطاء وأخذ الملحوظات و تطبيق الإمتحانات القبلية والبعدية والبعد بعدية وكذلك الملاحظة الدقيقة لمدة أربعة أشهر بمعدل ثلاث جلسات كل أسبوع وقد تراوحت مدة الجلسة من ساعة ونصف إلى ساعتين. تهدف هذه الورقة أيضًا لكلإستفادة من فلسفة ما وراء المعرفة يِّ التخطيط للاستراتيجية والتخطيط لساعة التعله. علاوة على ذلك ، يتم استخدام فلسفة ما وراء المعرفة هنا لتقييم مهارة الفهم القرائي ، وكذلك قياس عملية الاستبقاء لأثر المعلومات هِ الذاكرة من خلال الإختبارات البعدية وما بعد بعد ، ولتقييهم عمليتي التعليهم والتعله، والقضية الفريدة ، هي استخدام منهجية دراسة الحالة يِّ تدريس الترجمة لملاحظة حتى القليل من التغيير ِِ أية مهارة فرعية أثناء عمليتي التعليه والتعلهم. وهذا يعني أن الباحثة هدفت إلى تعزيز ليس فقط عملية التعلم ولكن أيضًا عملية التعليهم من خلال إستر اتيجية شاملـة.

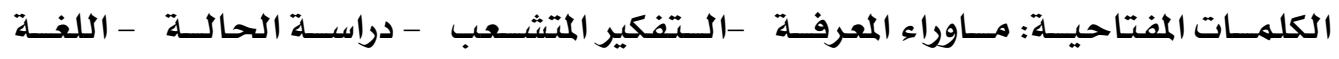

\section{.Introduction}

$$
\text { الإنجليزية - التفكير الذكي }
$$

Poor written English is now a common mistake in everyday life that cannot be denied. It should have more focus in research. Writing as one of the most important elements in the process of teaching English language has now pretended to be the most important. Once language teachers are aware of their students' perceptions, they can plan and implement methods and activities 
that would encourage learners to get involved more in the English language learning process. To enhance such a process, the use of metacognition for planning to such a process is a bright issue.

One of the main problems in the students' performance is the use of Prepositions used in Arabic and English language which have different purposes. Some prepositions in English have their equivalents in Arabic; however, there are also a few that do not have. Pittman recognized that English prepositions are difficult to learn and teach. Takahaski in 1969 agrees with Pittman that using preposition properly is one of the major problems for learners of English. Arab students learning L2 (English) used to depend on their L1 prepositional knowledge to understand the use of prepositions in L2. This posits difficulties for them because L2 prepositions are difficult to be learned. In their study, Lakkis \& Abdul Malak (2000) revealed that Arab learners didn't use prepositions with verbs such as like, compete, wait, result, collide, and engage because these verbs in their Arabic equivalence do not use prepositions. However, when using English verbs whose Arabic equivalence use prepositions, most learners used the verb 
with the preposition correctly. Most of the English prepositions do not have literal equivalents in L1. And there are many prepositions in English that have the same function since "prepositions seldom have a one to one correspondence between English and Arabic. An Arabic preposition may be translated by many English prepositions while and English usage may have many Arabic translations"; this posits difficulties for the students because then they are unable to choose which preposition to use.

Research indicates also that differences in the structures of L1 and L2 and differences and/or similarities of collocations of the two languages can lead to interference for L1 learners while learning their target language L2. Collocation means "sequence of lexical items which habitually co-occur, but are nonetheless fully transparent in the sense that each lexical constituent is also a semantic constituent" (Curse, 1987, p 40). It is the "group of words which occur repeatedly in a language". According to Oxford Collocations Dictionary (2011) "the way words combine in a language to produce natural-sounding speech and writing."

\section{Statement of the Problem}


In the light of the previous discussion, the problem in this study can be stated in the poor performance of the third year students in learning English as a Foreign Language in secondary stage students. The lack of coherence between learning grammar, and vocabulary. The defect in how word, statement, text, context relate to one another. There is a defect also in students' performance in how to write a good statement. And in how to link language levels (word, sentence, text, and context) together to write a good paragraph.

\section{Operational defenition of the idioms that may exist in this research}

Approach, method, and technique

In the present study the terms approach, method, technique and strategy are differentiated as follows:

"An approach" is a "set of correlative assumptions dealing with the nature of language teaching and learning". An approach is axiomatic. It describes the nature of the subject matter to be taught. "A method" is "an overall plan for the orderly presentation of language material, no part of which contradicts, and all of which is 
Educational and Psychological Studies Faculty of Education Journal Zagazig University

Vol. (36) No. (113), Part(2), October 2021

based upon, the selected approach". An approach is axiomatic, a method is procedural. (Anthony 1963: 63-7 cited in Richards and Rodgers 1986)

"A technique" is which actually taken place in a classroom. It is a particular trick, stratagem, or contrivance used to accomplish an immediate objective. Techniques must be consistent with a method, and therefore in harmony with an approach as well. (Anthony 1963: 63-7 cited in Richards\& Rodgers 1986)

"A strategy" is an elaborate and defined plan of action. (Hyper dictionary online 2003) In the present study, the term "strategy" is used to refer to the Radiant Thinking Strategy, while the term "approach" here is reffering to "the Metacognition Theory". The term "Teccniques", refers to "mind maps, concept maps, conceptual diagrams, and visual metaphors"as means of the Radiant Thinking strategy. The term "Method" in this research is used to refer to "methods of data collection".

\section{Metacognition}

"Metacognition" is the higher order thinking that enables understanding, analysis, and control of one's cognitive processes 
especially when engaged in learning. Lin, X. (2001) defines metacognition as the ability to understand and monitor one's own thoughts and the assumptions and implications of one's activities. To Fry (2008) metacognition is "the activities of monitoring and controlling one's cognition. In other hand it is 'the process of monitoring and controlling learner one's cognition."

\section{Metacognitive Skills}

Brown (1987) pointed to metacognitive skills as "the voluntary control which learners have over their cognitive processes". He identified four types or meteognitive skills; " 'Prediction' to assess task difficulty, 'Planning' things that should be done for task execution, 'Monitoring' things to know to attain objective, and 'Evaluation'".

\section{Processes Pertained to the Memory}

As scientists said; "There are three fundamental memory processes: encoding, retention, and recall. Encoding allows converting the perceived information of interest into a construct that can be retained in the brain. It is the first stage of creating a new memory in the brain. Retention is the storage of encoded 
information in the brain. Retrieval or recall is the re-accessing of retained events or information in the brain". ( Amin, H. U., \& Malik, A. S. (2014)

Memory processes like retention and recall. Memory is the route by which the acquired information is stored

The conventional concept of learning and retrieval is that learning takes place during studying, while retrieval helps to assess the learned content.

\section{Attention}

Attention is "the concentration of the mind on a single object or thought, especially one preferentially selected from a complex, with a view to limiting or clarifying receptivity by narrowing the range of stimuli. As human memory has a limited capacity, it is crucial to determine the information of interest to be encoded and subsequently retained. Attention helps the brain to encode items selectively into memory". (Amin, H. U., Malik, A. S., \& Kamel, N. 2014) 


\section{The Effect of the Radiant Thinking Strategy \\ Based on Metacognition Theory on Smart \\ Thinking (Case Study) \\ Asmaa.M.Abdullah Prof. Dr. Mohammad Hassan \\ Prof. Dr. Michael Abdel Masseeh}

\section{Retention}

Retention is the storage of encoded information in the brain. (Amin, H. U., Malik, A. S., \& Kamel, N., 2014).

\section{Retrieval}

Retrieval or recall is the re-accessing of retained events or information in the brain. (Amin, H. U., Malik, A. S., \& Kamel, N., 2014).

"The human memory system" informally refers to "the capabilities of learning new skills and experiences, storing what has been learned, and reusing experiences and skills; In daily life, we take in new information and store it in our brain, maintaining it and recalling it depending on our needs. This happens because our brain has these capabilities". (Amin, H. U., Malik, A. S., \& Kamel, N., 2014). 
Educational and Psychological Studies Faculty of Education Journal Zagazig University

Vol. (36) No. (113), Part(2), October 2021

\section{Reading Comprehension}

Reading comprehension refers to "the ability of readers to understand the surface and the hidden meanings of the text using meta-cognitive reading strategies. Reading comprehension is a complex process involving a combination of text and readers. (Ahmadi, Hairul, \& Pourhossein, 2012; NICHHD, 2000)

\section{Radiant Thinking Strategy}

Buzan (1993) describes Radiant Thinking as "a Branching Association Machine (BAM). This machine describes the mind as always radiating from a central image. Every image has a never ending chain of branching patterns or images away from this central image".

\section{Mind Mapping Technique}

It is also called a concept map; it can be defined as "a picture used to show concepts arranged around a central idea". It is used as a documentation technique in order to visualize the structure of a 
topic. Concept maps can be created on paper or whiteboards or with specialized software.

\section{The Meaning of Translation}

Translation means: the interpretation of a language through using another. It can also be used as a teaching strategy for learning foreign languages. O‘malley (1987:77) describes translation using the first language as "a base for understanding or producing the second language". Accordingly, translation is a natural, useful and essentially communicative activity, as known, using of L1( first language) in EFL classes involves saving class time which general learners of the language have to perform, whether or not they have had any formal training as translators or interpreters. Translation as Nord (1997) views" it is a purposeful activity that requires a unique competence which has thus far proved difficult to identify".

In a foreign language teaching situation, it is much more reasonable to focus primarily on building up the learners' knowledge of the system. This can be done much more naturally if we help learners make the appropriate connections between what is known, and what is new. Besides, as Cook (1992:584) points out, 
Educational and Psychological Studies Faculty of Education Journal Zagazig University

Vol. (36) No. (113), Part(2), October 2021

the L1( first language) is present in the L2( second language) learners' minds, whether the teacher wants it to be there or not. The L2 knowledge that is being created in them is connected in all sorts of ways with their L1 knowledge. The way many modern teaching methods treat the L2 in is isolated from the first language, and is reminiscent of the ways of teaching deaf children language by making them sit on their hands so that they cannot use sign language. (Cook, 1992)

Translation has been called "inter-language paraphrase", or "paraphrase intra-language translation". In both, as Fuches mentioned; "The objective is to take a piece of information and recode the meaning in a different linguistic form. In one case the form is a different language and in the other the form is within the same language". (Fuchs, 1982)

"Smart thinking" means knowing;

I. How to work out and express your main ideas - plan your communication of ideas so that they can be clearly understood - check to see if you have covered all the important parts of your topic. 
II. How to establish a framework or structure in which your basic facts and evidence make sense.

III. How to present ideas by linking them together to convince readers of your conclusion. Moreover, we must also relate thinking to knowledge and information (what we think about). (Smart Thinking p.2) (Mathew Allen Perth, 2003)

Mathew Allen in his book published by Oxford 2003 added that; there are four distinct 'levels' of language use that build together to create 'language' as we know it. The first level is a word - for example, 'student' or 'reasoning'-which is the basic unit of language. Words have meanings, usually more than one, and often multiple meanings are 'denotative' (that is, what the word explicitly says) or 'connotative' (the more subtle, 'hidden' meanings of words). When we put some words together, we get the second level of language: a statement, such as 'there are several hundred students who have studied smart thinking at Curtin University'. We probably think of statements as being the same things as sentences, but they are not. In the following example we can see how one sentence can be made up of more than one statement: 'We use 
reasoning everyday of our lives, but most of us have no formal training, and the more practice and the more training, the better we will be at it'. The first statement is 'We use reasoning everyday of our lives'; the next is 'most of us have no formal training [in reasoning]'; the third is 'the more practice and the more training, the better we will be at it [reasoning]'.

The third level of language use is the text, which is made up of any group of statements, such as the sentence above. Now, usually, the texts we encounter are much longer than just a few statements (for example, this book is a text, as is a newspaper article). But, remembering that we are talking about something different to 'natural' things we read and hear, we define a text as a group of statements that is of any length, so long as there is more than one statement and these statements are related to one another in some way. Texts are not just lists of statements; they are groups of connected statements. In the example of a multi-statement sentence from the previous paragraph, as well as in single statements, words like 'but' or 'and', and punctuation like commas and semi-colons, are not included in the statements. They act both to distinguish one statement from another and, at the same time, to join together the 


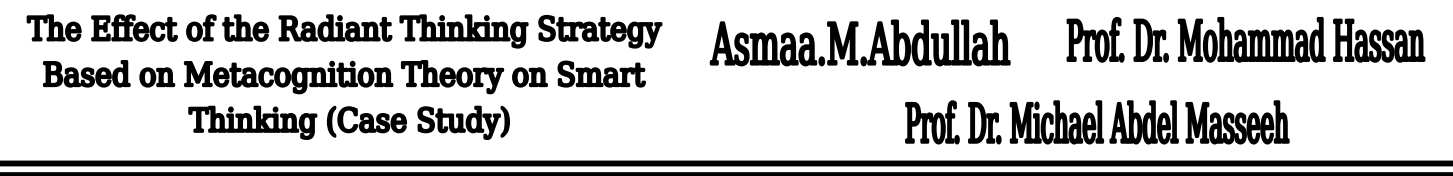

various statements to make a text. Practical communication via texts depends on the way these words connect the statements. Finally, the last level of language use is the context, which consists of all the elements outside a particular text that make it meaningful. A context for this book, for example, would include (at least) the purposes and goals of its author and readers, the assumptions about the meanings of words and ideas that lie behind it, and other texts that, though absent, are implicitly connected with what is being written and read here. (Mathew Allen Perth, 2003,Smart Thinking p. 24, 25)

Mathew added that; "What makes assumptions dangerous is not their content but, rather, that they are not consciously considered and tested to see if they are correct. Smart thinkers must be capable of understanding how each of these four levels of language use relates to one another, and of how to write good statements, link them together to make a text, and consider the contextual factors that bear upon their texts". 


\section{the Research limitations}

The study will be conducted upon three students (girls) at (Al Salam Secondary School), Cairo. Yet, it is important to put in consideration that; 1) the small number of students selected as participants in this study is a usual practice for a qualitative case study. 2) the duration of the study is four months for the implementation, and two weeks for assessing retention and memorizing.3) the study is limlited also to texts in the two books that are allotted for students at the third year secondary in Al-Azhar for special level.

\section{the Research Questions}

1 - How can we apply Radiant Thinking Strategy on students to improve the smart thinking skill when translating from English to Arabic?

2 - How far could teaching with such a new adopted strategy offer any interest here? 


\section{The Effect of the Radiant Thinking Strategy \\ Based on Metacognition Theory on Smart \\ Thinking (Case Study) \\ Asmaa.M.Abdullah Prof. Dr. Mohammad Hassan \\ Prof. Dr. Michael Abdel Masseeh}

\section{The Research Assumption}

As the radiant thinking increases, the student smart thinking skill in translation will be improved.

\section{Aims of the research}

This research aims at improving smart thinking skills which are;

1- How word, statement, text, context relate to one another.

2- How to write a good statement

3- How to link them together to write a good paragraph.

\section{METHOD}

\section{Participants}

In this case study research, three students in the third year of the secondary school were chosen in the age of eighteen years. All of the learners had been studying English for a minimum of eleven years. This prospective case study was carried out on the three students for a lapse of four months in 50 sessions, for three sessions a week. Each session longs for 90 minutes. The students 
Educational and Psychological Studies Faculty of Education Journal Zagazig University

Vol. (36) No. (113), Part(2), October 2021

are affiliated to the third year at Al Azhar secondary school Administration, Cairo. The two books of the examples taken in this research are allotted for the third year at Al Azhar secondary school as a special level. Three students of the same sex (girls) are invited to participate in the research. The sample is randomly chosen. Texts chosen as examples to deal with are natural texts selected from the two books; "Spot Lights on Islam", and "Study science". The researcher preferred not to use artificial texts for the process of learning translation to avoid the problem of translating isolated sentences.

Study Duration: from January 2020 to April 2020 .

- The Research Design

- * * Methods of data collection

Qualitative and quantitative methods of data collection are adopted. The qualitative method will be used to collect and analyze data while a quantitative method will be used to further strengthen the qualitative data. The independent variable in this research is the Radiant thinking Strategy including (mind maps, concept maps, conceptual diagram, and visual metaphors). Choosing from them is 
depending upon the case and the best choice is when interchanging among them smoothly. The dependent variables will be smart thinking skills including how (word, statement, text, and context relate to one another 2) How to write a good statement, and 3) How to write a good paragraph). Students' tests scores will be analyzed. This research is depending upon the results of the articles that discussed the difference between concept maps, mind maps, conceptual diagrams, and visual metaphors as being techniques of Radiant Thinking Strategy. In Novak's article in 2006; he argued that the combination of these four visualization types can play to the strength of each other. In another research by Martin J Eppler, it is proven that the different visualization formats can be used in complementary ways to enhance motivation, attention, understanding, and recall. (Martin J Eppler1, 2006)

In another research by Martin Davies, 2010 software mapping tools are discussed. His paper suggests that the choice of a given mapping tool largely depends on the purpose or aim to which the tool is used. However, the paper also suggested that these tools may be converging to offer for educators complementary functions. 
Educational and Psychological Studies Faculty of Education Journal Zagazig University

Vol. (36) No. (113), Part(2), October 2021

Furthermore it suggested that this development provides new teaching and learning tools for both students and teachers that will enrich and provide new directions in education in the future.

- The four methods of Radiant thinking strategy will be used in complementary in this research depending upon the purpose of translation and the learning environment. And the software maps will be used by the use of the app. "MindMaster". These four methods are,

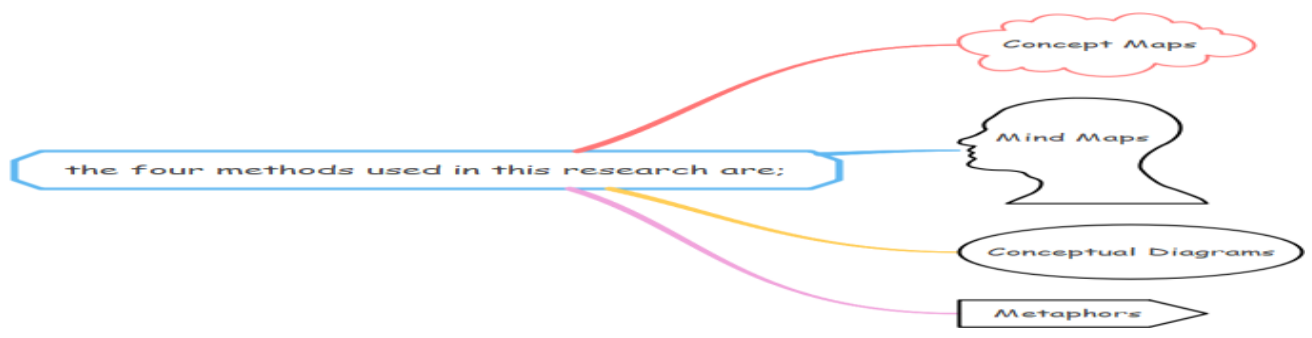

- Figure I

- The Four Methods Used In This Research

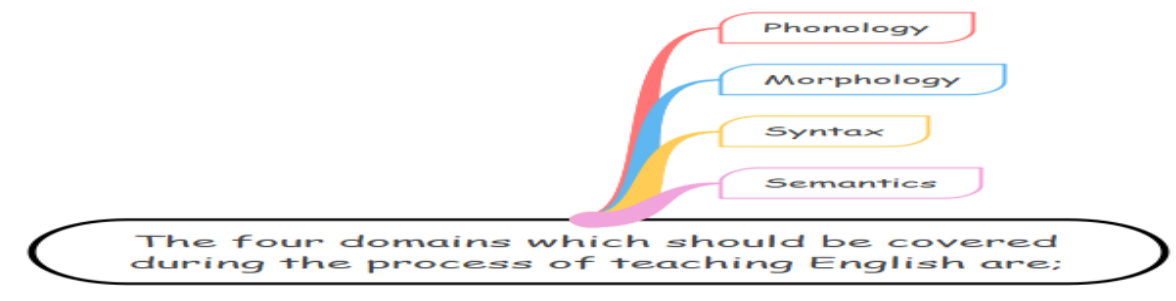

- Figure II

- The Four Domains Which Should Be Covered During the Process 


\section{The Effect of the Radiant Thinking Strategy \\ Based on Metacognition Theory on Smart \\ Thinking (Case Study) \\ Asmaa.M.Abdullah Prof. Dr. Mohammad Hassan \\ Prof. Dr. Michael Abdel Masseeh}

Phonology will be excluded due to the fact that the researcher will work on written skills.

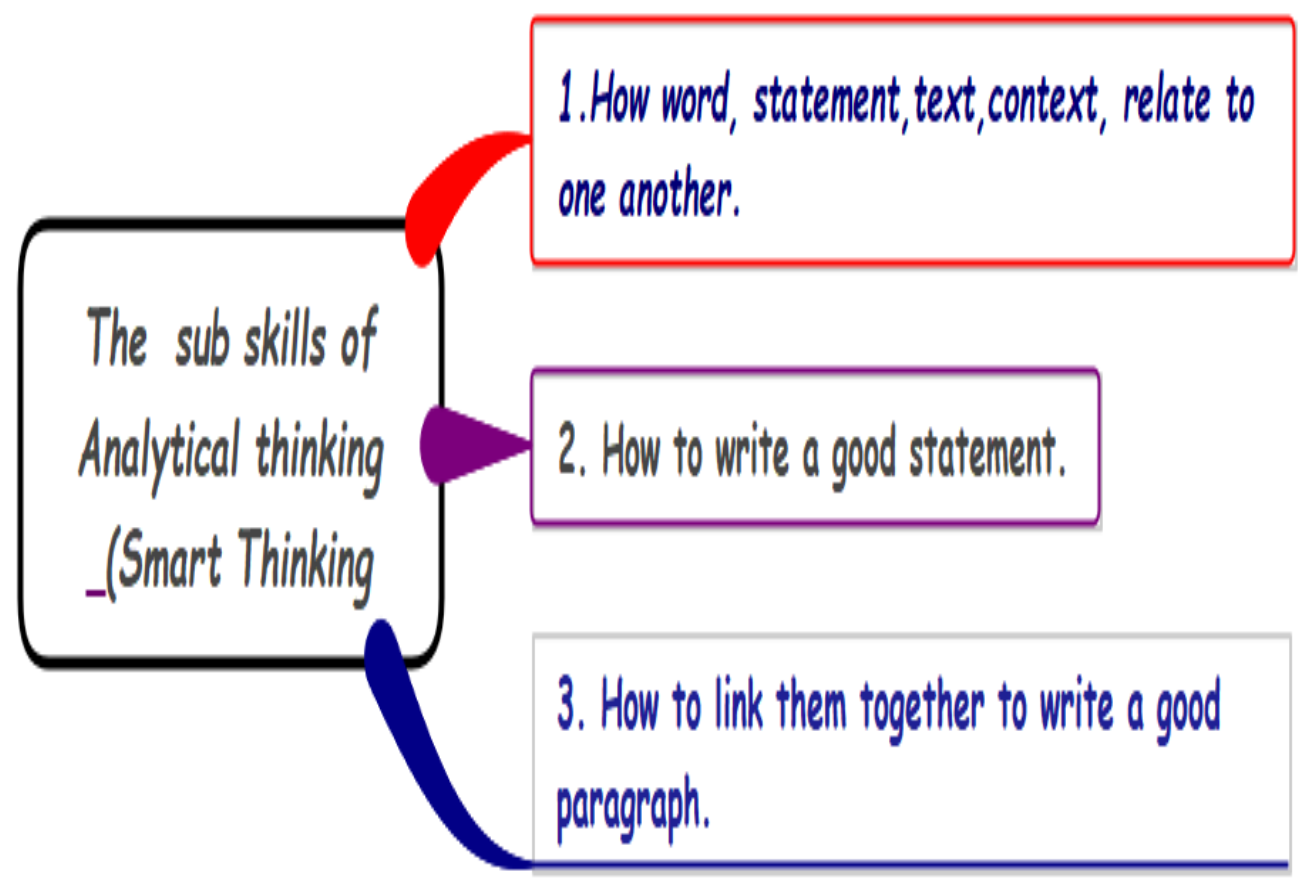

- Figure III

- The Sub Skills of Analytical Thinking, or Smart Thinking

The two words; Analytical, and smart will be used alternatively

along the study. These sub skills are extracted according to

Mathew Allen in his book "Smart Thinking” 2004, p.20. 
Educational and Psychological Studies Faculty of Education Journal Zagazig University

Vol. (36) No. (113), Part(2), October 2021

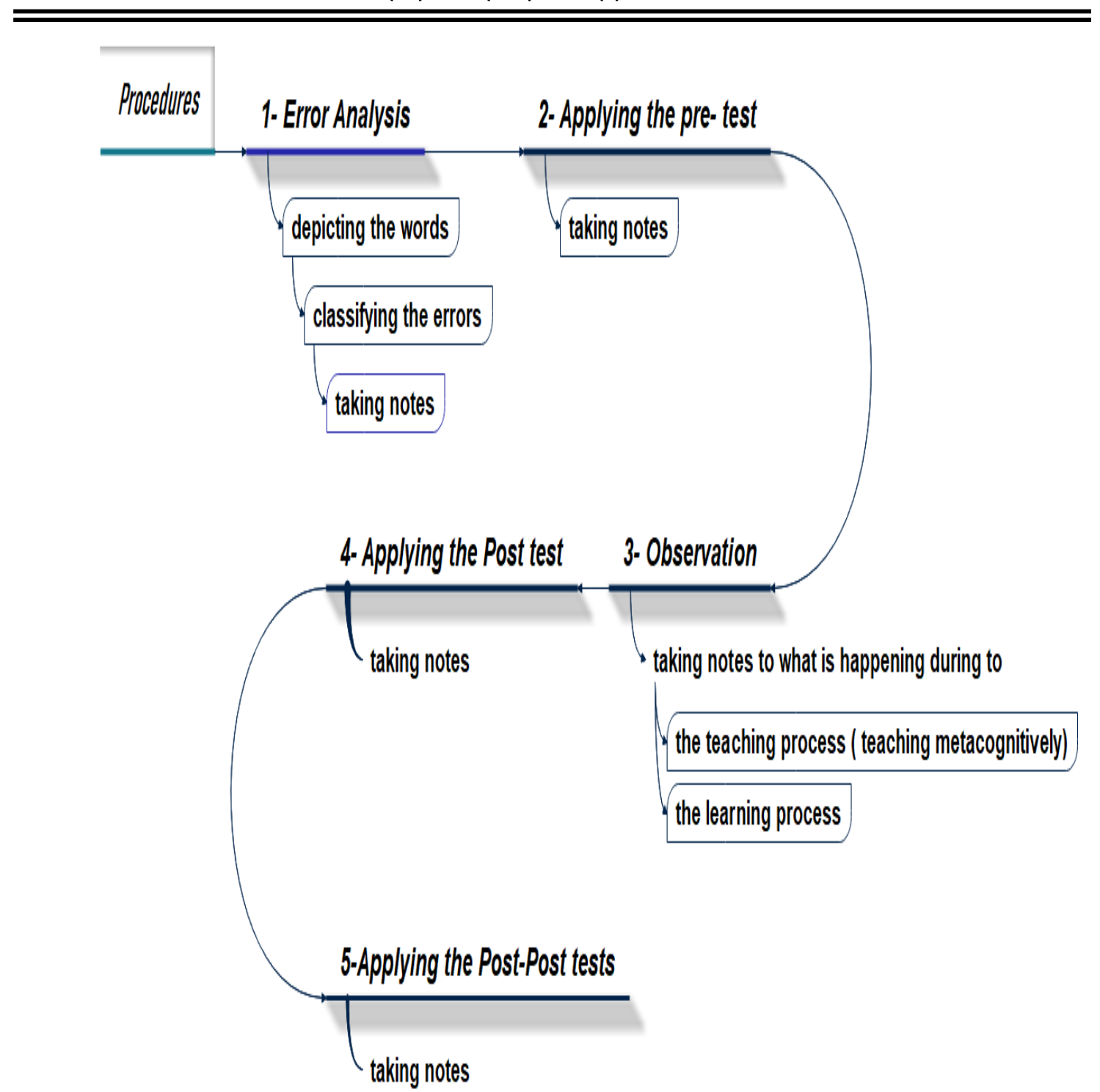

(Figure IV)

The Procedures of the Study 


\section{The Effect of the Radiant Thinking Strategy Asmaa.M.Abdullah Prof. Dr. Mohammad Hassan Based on Metacognition Theory on Smart

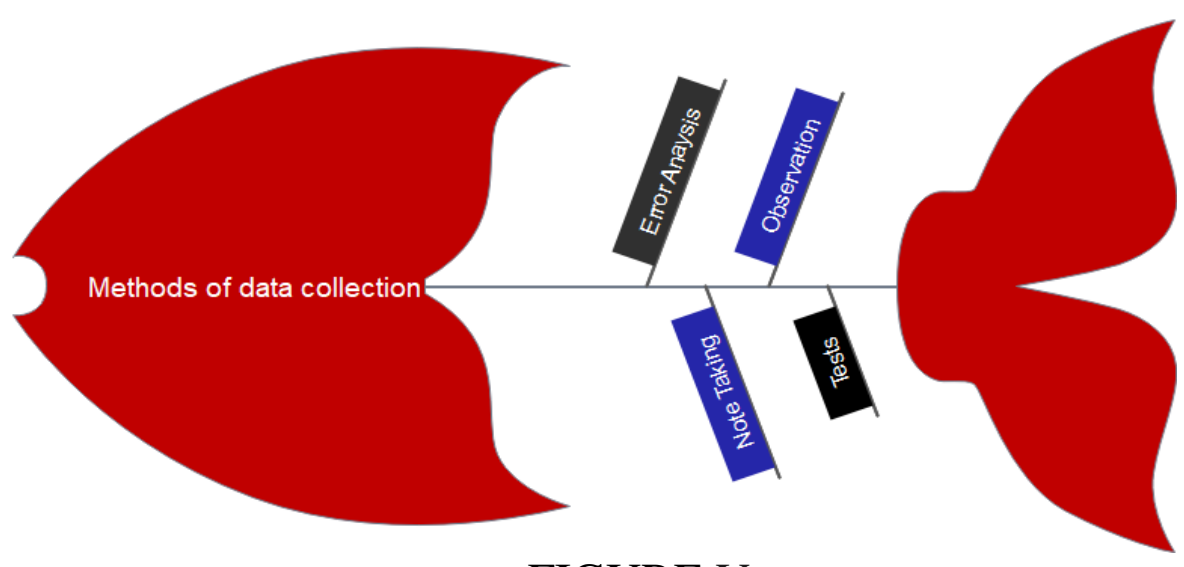

\section{FIGURE V}

Methods of data collection

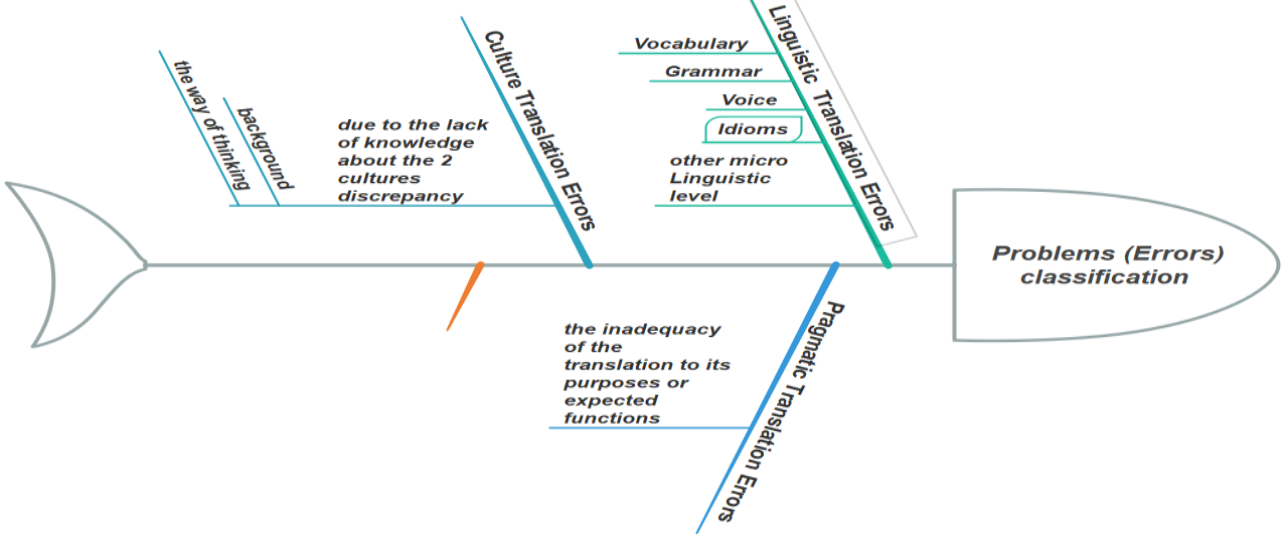

(Figure VI)

- Types of Error Analysis in Translation (Zhang, L. ,2016) 
Educational and Psychological Studies Faculty of Education Journal Zagazig University Vol. (36) No. (113), Part(2), October 2021

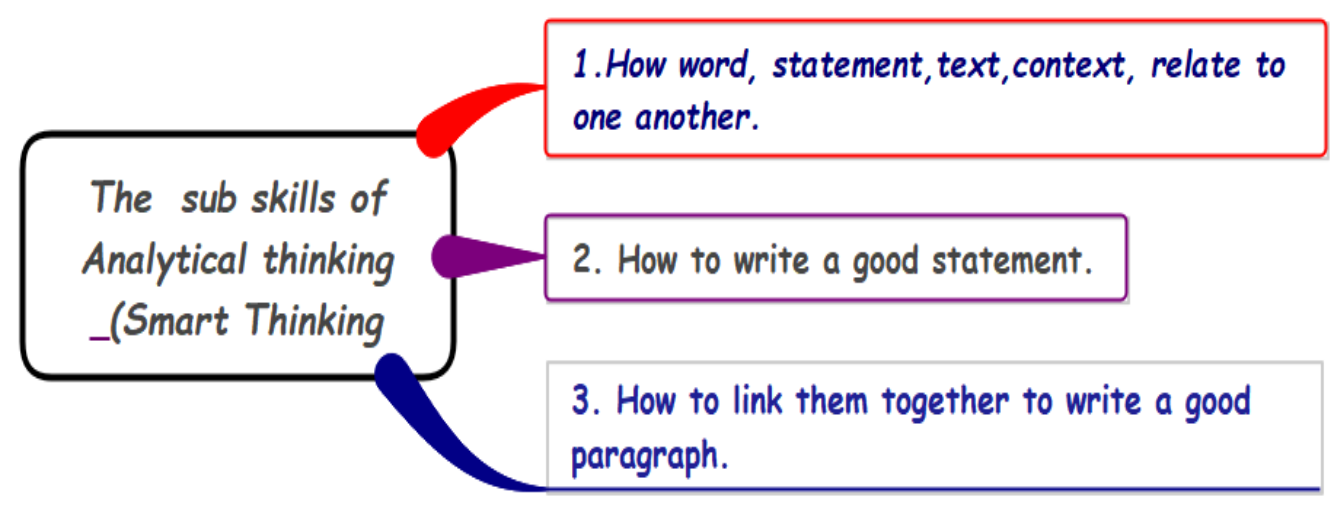

- Figure XI I

- The Sub Skills of Smart Thinking or Analytical Thinking

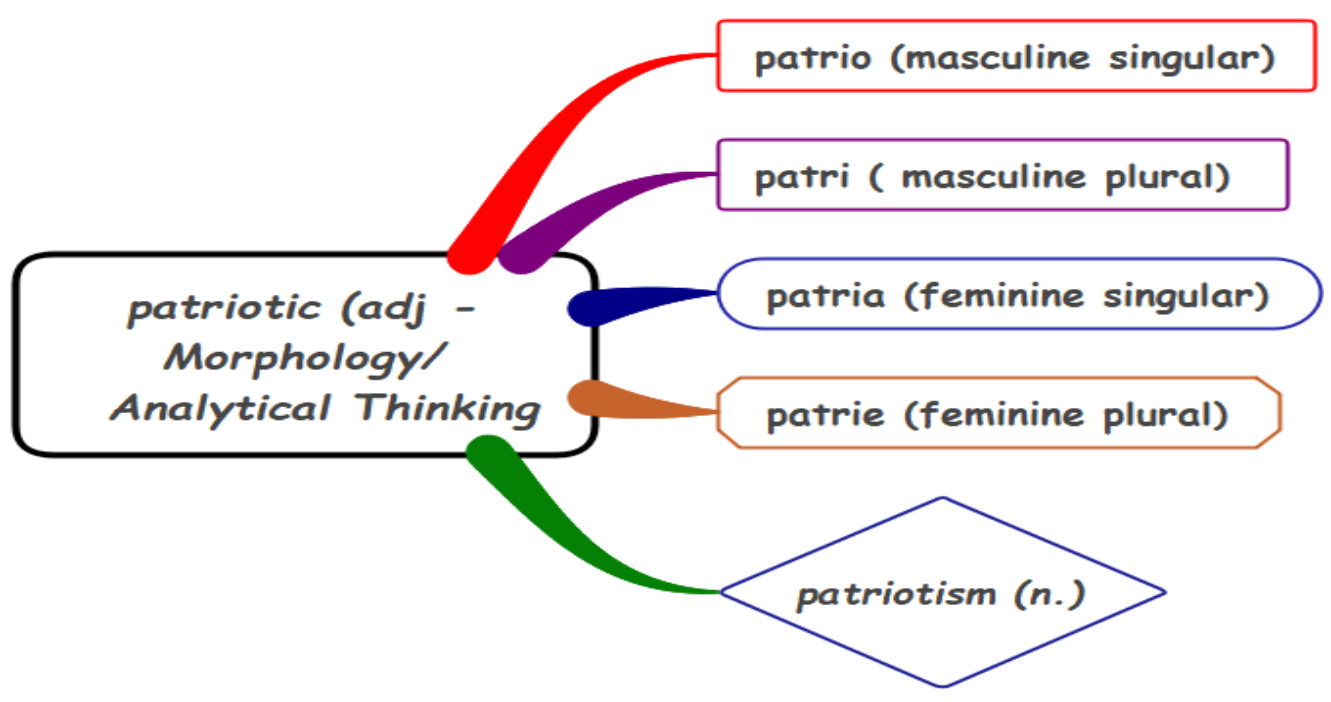

Figure VIII

An Example of Improving the Smart-Analytical- Thinking Skill through Morphology 


\section{scientific- \\ Semantics/ \\ Analytical \\ Thinking}

\section{Scientific Revolution}

\section{Scientific Notation}

\section{Scientific Law}

\section{Scientific Theory}

\section{FIGURE IX}

An Example of Improving the Smart Thinking Skill through

Semantics

- 348 - 


\section{Educational and Psychological Studies Faculty of Education Journal Zagazig University Vol. (36) No. (113), Part(2), October 2021}

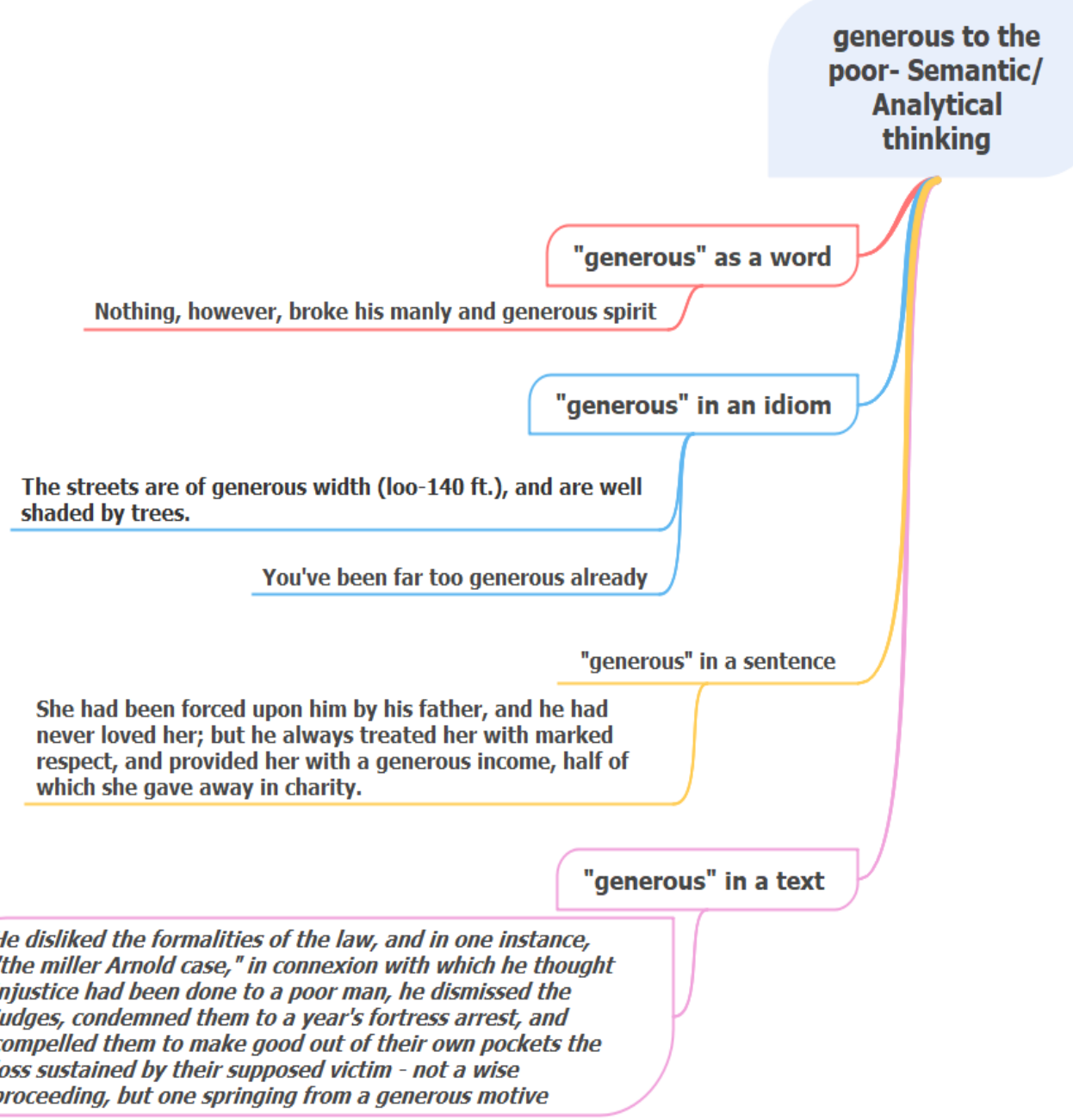

- FIGURE X

- Th Use of Concept mapping technique to improve the the Three Sub Skills of Smart Thinking through Semantics 


\section{The Effect of the Radiant Thinking Strategy Asmaa.M.Abdullah Prof. Dr. Mohammad Hassan Based on Metacognition Theory on Smart Thinking (Case Study) \\ Prof. Dr. Michael Abdel Masseeth}

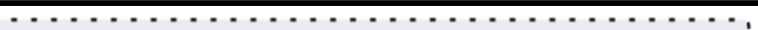

def. An inclination towards apatricular characteristic or

type of behaviour

e.g (1) Substanceshave no tendency to expand unless

tendency-

they are heated.

Syntax/

Analytical

e.g (2) He has a tendency towards things.

Thinking

e.g (3) There is a tendency towards regional cooperation.

e.g (4) The drug is effective but has a tendency to cause headache.

\section{FIGURE X I}

An Example of Improving Smart Thinking through Syntax

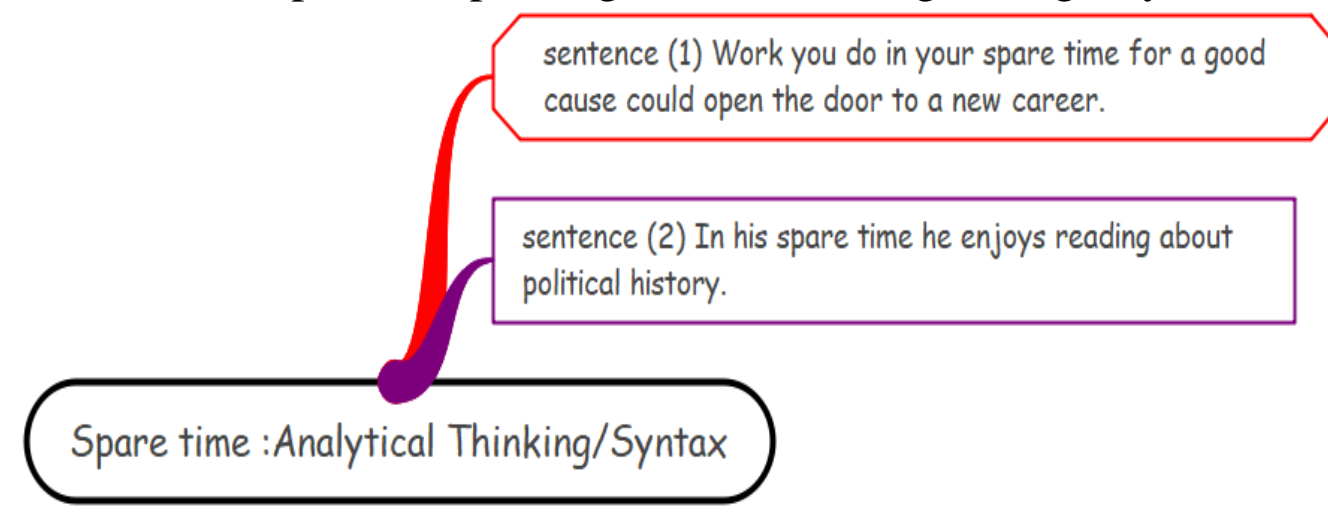

- FIGURE XI I

- An Example of Improving Smart Thinking through Syntax 
Educational and Psychological Studies Faculty of Education Journal Zagazig University

Vol. (36) No. (113), Part(2), October 2021

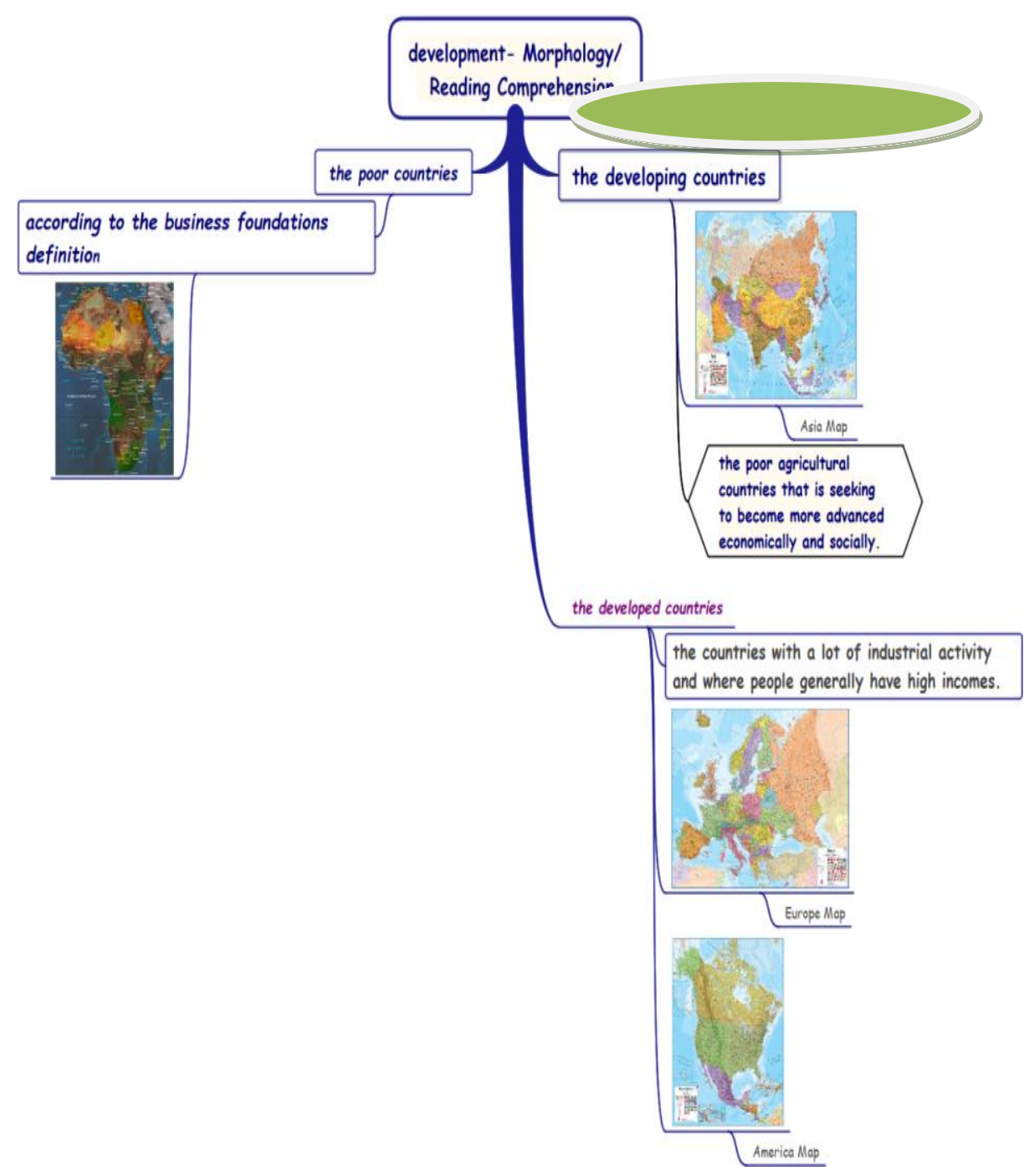

\section{FIGURE XI I I}




\section{The Effect of the Radiant Thinking Strategy Asmaa.M.Abdullah Prof. Dr. Mohammad Hassan
Based on Metacognition Theory on Smart Thinking (Case Study) \\ Prof. Dr. Michael Abdel Masseeth}

e.g. They barely notice that.

e.g. He had barely reached twenty when he was exiled.

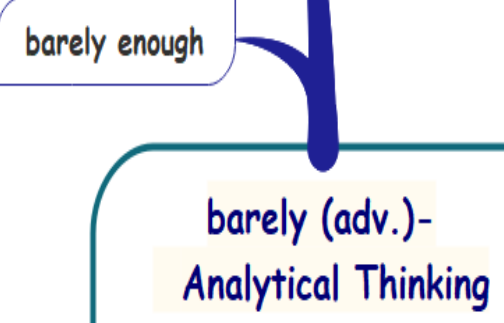

- Figure IX.

- .A chart by the Participants to Improve Analytical thinking.

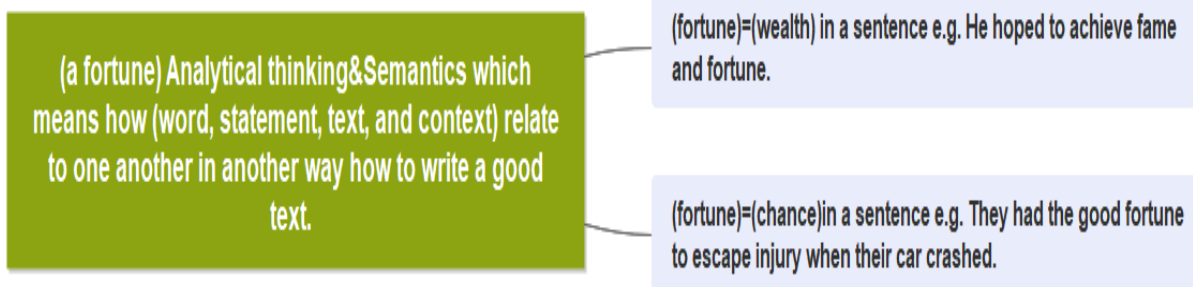

Figure X

. A Mind Map to improve the Skill of Analytical Thinking through Semantics.

The word "fortune" in a context. 


\section{Educational and Psychological Studies Faculty of Education Journal Zagazig University Vol. (36) No. (113), Part(2), October 2021}

The researcher asked the three students to find or creat a text involving the word "fortune".

- $\quad$ The first text was;

- $\quad$ "Aman had a streak of good fortune.This year saw declining fortunes for the company.Their economic fortunes have not been good. As he comes from a family with a large fortune, he has good fortune on his side. A four-leaf clover is supposed to bring good fortune."

- $\quad$ The second context was;

- $\quad$ "They are hoping to reverse their bad fortunes. He knows his fortune can change quickly. They hope their fortunes will improve. She was told her fortune by a fortune-teller. They made a great fortune through real estate. He won a fortune in the lottery. He inherited his fortune from his grandfather."

\section{The third context}

"She left her fortune to charity. Her husband lost his fortune by gambling. Her son's baseball card collection is worth a fortune now."

Or, "My textbooks cost a fortune. He spends a fortune eating out. She paid a fortune for her new car. She inherited a fortune from her 


\section{The Effect of the Radiant Thinking Strategy Based on Metacognition Theory on Smart Thinking (Case Study) \\ Asmaa.M.Abdullah Prof. Dr. Mohammad Hassan \\ Prof. Dr. Michael Abdel Masseeh}

grandparents. He made his fortune in real estate. He made a fortune on his investment. She didn't believe the fortune teller." The students make errors in the word "native" which can be classified as an error of vocabulary lingustic translation errors. When translating the word, the meaning can be missed. That can be redeemed by the use of mind map which can provide development with enhancing the skill of production which includes the subskills of;1) how to translte the word seperately,2) how to translate the word in a sentence, and 3) how to translate the word in a paragraph.

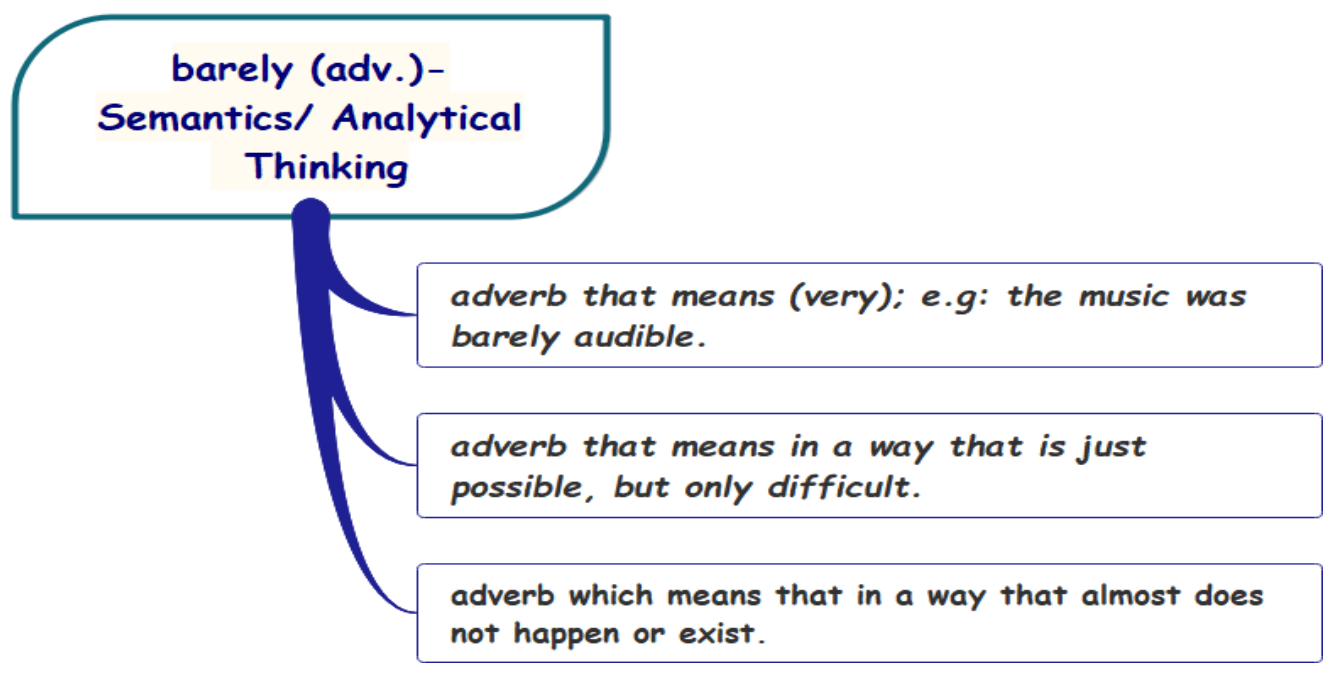

Figure XI

An Example of a Mind Map to Improve the Skill of Analytical Thinking Through Semantics. 


\section{Findings}

The results pointed to that the four methods of Radiant thinking strategy had a significant effect on improving smart thinking skills by the participants because the results from the pretest and posttest scores for them showed that there was also a significant difference in the performance of the participants.

The findings of the current study are in agreement with Li (2010) who illustrated the cognitive motivation of English and Chinese idioms based on the conceptual metaphor theory which found that most English and Chinese idioms were motivated by conceptual metaphors in a systematic way furthermore the conceptual metaphors accelerated the teaching and learning of idioms. In another study by Gibbs, Bogdanovich, Sykes, and Barr (1997), the role of conceptual metaphors in idioms comprehension was examined. What they were interested in was to find whether people quickly accessed conceptual metaphors each time an idiom was encountered in discourse. They found that "conceptual metaphors could under some circumstances be quickly accessed during idioms 


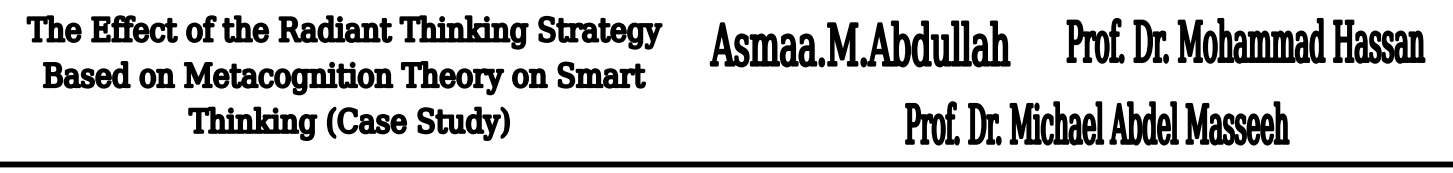

comprehension, and people accessed the appropriate conceptual metaphors when they processed some idioms".

Kömür and Çimen's (2009) findings also are in consonance with the findings of this study. They found that conceptual metaphors affected teaching idioms in an L2 context. They developed lesson plans, and the lesson plans contained activities that enhanced the L2 learners' metaphorical perceptions in the L2. The results of their study showed that the implementation of these lesson plans enhanced the L2 learners' metaphorical awareness and enabled them to be successful in understanding idioms. Also, the results pointed to the fact that the effect of conceptual metaphors on learning idioms was more than that of traditional methods. The result from the pretest and posttest scores showed that there was a significant difference between the mean of performance of the participants. Other researches serve in solving partial problems of the main problem of translation as Samani, E. R. (2012) who examined "The effect of conceptual metaphors on learning idioms by 12 learners". This was published on International Journal of 
English Linguistics, 2(1), 249.so, the application of this study for educating translation as a whole from English to Arabic shall make a change in the field of translation.

The performance of the participants in learning idioms, vocabularies, synonyms, reading comprehension, researching, analytical thinking, and constructing is significant by the complementary use of mind mapping, concept mapping, conceptual diagrams, and conceptual metaphors which were better than that of the traditional methods because the mean scores of the pretest and posttest in conceptual metaphors was more than that of traditional methods. It shows that conceptual metaphors facilitated learning translation skills. The participants who had learned idioms by the conceptual metaphor instruction could keep idioms in their mind better because they were familiar with the literal and metaphorical meaning of the words. Also, the participants who learned idioms by the traditional methods could learn idioms but they failed to draw the meaning of the idioms because their metaphorical awareness was not raised. In addition, they were not aware of this fact that most idioms are products of our conceptual system and are not simply a matter of language. 
Learning vocabulary, expressions, and idioms presented in an organized fashion is easier than random lists of idioms. Organizing lexis, idioms, and expressions in groups is effective for L2 learners because it facilitates connecting the new items with already familiar ones.

Therefore, it is reasonable to introduce L2 learners grouping of words, idioms, and expressions that are made up of familiar items and just a few new ones. Idioms can be grouped according to conceptual metaphors, or the source domains they have in common. For example, the expressions used to describe anger can be grouped under headings like ANGER IS HEAT (e.g., He's blowing off steam, He blew up at me or She's funning). Another implication of this study is that idioms should be grouped according to conceptual metaphors. Therefore, in this way L2 learners can learn idioms better and increase the chance of remembering them longer.

The book; "Mastering Idiomatic English" was chosen to help the participants. Whenever I ask the participants where their difficulties in learning English lie, they gave me one of two 
responses: they either say that they have trouble with verb tenses, or they reply that they do not have enough vocabulary.

One of the most effective ways for students to incorporate new words and expressions into their language is through the study of idioms and idiomatic expressions. Indeed, the Oxford Dictionary of English Idioms (1993) states in its introduction that the "accurate and appropriate use of English expressions which are in the broadest sense idiomatic is one distinguishing mark of a native command of the language and a reliable measure of the proficiency of foreign learners". That is, once students are able not only to understand idiomatic expressions, but also to produce them, we can say that they have attained a high level of second-language proficiency by looking into the study of English from what one may name as "a mathematical way" in which triangles, and actions like are taken place not only on the paper, but in their minds also. And that is the thing which the researcher was looking forward before the implementation of the study.

Many activities may add to the outcomes of the study. For example; Boers (1999), Deignan, Gabryś, and Solska (1997), Lazar (1996), and Liu (2008) offered sample activities that aim at raising 
metaphoric awareness and give L2 learners the opportunity to make cross-linguistic comparisons and express themselves in metaphorical terms. These activities comprise gap-filling exercises, metaphoric themes recognition, activities applicable to both monolingual and multilingual groups, making sentences using idioms, telling stories based on pictures, retelling and add-on stories, idiom notebooks and flashcards, association of idioms with mental images, hypothesizing and learning the origin of the idioms, using idioms dictionaries, playing idiom games, replacing marked expressions with idioms, and completing a story or a paragraph. Cultivating L2 learners' metaphorical awareness can be one of the implications of the study. The present research engaged L2 learners in communicative activities (and used some of the abovementioned activities); then, the L2 participants applied their own metaphorical sentences. Next, they wrote one paragraph for each unit and used the idioms in their written discourse. In this way, their metaphorical awareness was boosted.

The most important implication of this study is that L2syllabus designers and curriculum developers can include 
Educational and Psychological Studies Faculty of Education Journal Zagazig University

Vol. (36) No. (113), Part(2), October 2021

conceptual metaphors, conceptual diagrams, and concept maps in

L2 textbooks as an applicable and suitable method in teaching idioms.

In fact, this research takes into consideration the levels of L2 learners and examined the study on different proficiency levels. Therefore, it is hoped that future researchers can take into account the matter of concrete and abstract words. Further research can be done on this matter whether L2 learners can use different mappings automatically when confronting written translation or not.

In educational systems, the theory of studying and testing is followed. Learning occurs during lectures, reading, and study groups. Tests have been designed to judge what has been absorbed or learned by studying. These tests are considered assessments or evaluations of learned knowledge. Researchers studied learning by trials of study (S) and a test (T). The critical supposition is that learning occurs through study phases, while a test simply measures what was learned in previous study phases (of STSTST ... order). Recently, a study of reviewed evidence opposes this conventional perception: retrieval exercises during tests have often resulted in better learning and long-term retention than has studying. 


\section{The Effect of the Radiant Thinking Strategy Asmaa.M.Abdullah Prof. Dr. Mohammad Hassan
Based on Metacognition Theory on Smart Thinking (Case Study) \\ Prof. Dr. Michael Abdel Masseeh}

In related studies, Roediger and his colleagues in 2006 investigated the link between retention and learning with repeated testing, and they proposed that the repeated recalling of retained information led to better learning and long-term retention. In one experiment, participants were given a list of items to study under two different conditions. In one condition, the list was studied 15 times and tested 5 times, while in the other condition the list was studied 5 times and tested 15 times. A retrieval task after one week showed better learning and retention results in the repeated test condition as compared to the repeated study. These studies explained that testing/retrieval is a powerful technique of enhancing memory retention and recall performance. The implications of these are that students should test themselves repeatedly instead of studying the content frequently. However, feedback should be included in the frequent testing technique to avoid errors.

The results of this research are in accordance with another research by Karpicke, J. D., \& Roediger III, H. L. (2007) which concluded that "Repeated retrieval during learning is the key to 
Educational and Psychological Studies Faculty of Education Journal Zagazig University

Vol. (36) No. (113), Part(2), October 2021

long-term retention". Testing allows recalling stored information

from memory. It also minimizes the errors in the recall result and

helps to retain correct information. And repeated testing allows the

same neurons involved initially in learning to fire repeatedly. The

neuronal networks become more stable and synchronized, and

recollection of stored information becomes easier.

\section{Conclusions}

The study serves as a model for language teachers for any language, and for English teachers in particular. This research helps to compare teachers own perceptions and techniques with that of their students. Once language teachers are aware of their students' perceptions, they can plan and implement methods, and activities that would encourage learners to get involved more in the English language process, therefore lead to more language learning and positive attitudes towards their teachers. The research paves the way for both teachers and students of translation to use their own drawn map, or diagram in order to facilitate one's own process of learning.

In the present study, it has cleared that while students expect a good English teacher to have the ability to maintain every piece 
of information about language, the research pushes the students to be active enough to research about the information, draw their own map, and share knowledge with their mates which maintain positive classroom atmosphere.

This research suggests that, in practice effective teachers are able to strike the right balance while the process of learning. As trainees are likely to lack knowledge of the characteristics of a good EFL teacher, such a study would likely provide teacher education programmer with an opportunity to develop trainees' notions of being an effective EFL teacher.

Because of the diversity of the skills of translation adopted in the research, no matter good or poor readers, all the readers take care of skimming and scanning strategies, which are included in the comprehension sub-skills of cognitive strategies but good readers think more deeply to recognize and comprehend the texts adequately. Moreover, the idea expands to suit even bad readers for instance because bad readers may be good researchers, or good in the skill of analytical thinking. This research in our hands benefits 
from this diversity; it solves the lack in a skill by the mastery of one or even the three other skills.

As for the skill of reading comprehension, the research shows different sub skills for the main skill. Sheila W. Valencia and P. David Pearson, in their work with teachers in Illinois have developed an assessment system that mirrors the definition of reading they adopted. The driving force behind the system is that reading assessment should reflect the basic processes of constructing meaning from text;

they have found ways to assess summarizing in both open ended and recognition formats. In the open-ended version, students are asked to write down or verbalize what they consider to be the most important ideas, the theme, the central focus, or whatever else is deemed important. In the recognition format, students are provided with a set of summaries and asked evaluative questions about them.

On another hand, other researches show different sub skills. This diversity between researches in defining the subs kills helps to identify the sub skills according to the word, or the context which is very important. 
There is such a relationship with context while implementing the strategy within the four skills; while implementing the strategy in the field of semantics, the difference between connotation and denotation of such a word can be differentiated easily while mapping. Connotation includes the array of meanings the word may connote. Denotation refers to the precise meaning of a language. So, the use of mapping to draw the connotation arrays of a word or a context is useful.

\section{Discussion}

This study helps L2 researchers, and teachers to apply the four techniques of the radiant thinking strategy for teaching translation skills in the classroom, at university, as well as in the academic schedule.

Vocabulary teaching as an important part of semantics in teaching in senior high schools, and it is also a high process. English teachers need to constantly guide and help students learn and memorize English vocabulary, so that students can learn to learn by themselves and ultimately improve the effectiveness of 
Educational and Psychological Studies Faculty of Education Journal Zagazig University

Vol. (36) No. (113), Part(2), October 2021

English vocabulary teaching and learning. There is a significant difference in the test scores between before, and after the application of the study, students who are the participants have made greater progress. In the process of English teaching in senior high schools, English vocabulary teaching has always been a difficult problem. It has been proved effective and feasible to teach vocabulary by using relevant strategies that mainly teach vocabulary and word formation in context, so as to help students understand the meaning of new words and memorize vocabulary. Secondly, adopting relevant strategies in vocabulary teaching is conductive to brilliant students who try to learn English vocabulary by using relevant learning strategies, so as to enhance students' interest and effectiveness in English vocabulary learning

With the continuous development of society science and technology, the renewal of linguistic theories and the advancement of interdisciplinary studies, the scope of applied linguistics research has been expanding, and its definition has been extended from simple language teaching to all aspects of daily life related to language use. However, language teaching is still the most important research focus and core of applied linguistics. Although 
the sample size involved in this study is relatively small. The researcher chooses the participants, but she does not completely exclude the factors of students' willingness to learn. Therefore, there are some limitations in the study. Teachers should establish a comprehensive teaching system according to classroom teaching objectives, constantly learn advanced foreign teaching experience, and fully integrate it with domestic teaching characteristics. In the process of classroom teaching, not only teachers need comprehensive guidance to control the pace of teaching, but also students need to actively cooperate with teachers' classroom process and actively participate in classroom learning. In addition, teachers should communicate with students in time, understand the problems existing in students' practice, make a comprehensive analysis of students' practice, and adjust teaching strategies according to the analysis results. In the teaching system, it is also necessary to set up corresponding practice instructors, conduct special counseling investigation on students' practical work, and collect teaching cases, teaching plans and other materials from students' practice. To cultivate high-quality language talents, it 
Educational and Psychological Studies Faculty of Education Journal Zagazig University Vol. (36) No. (113), Part(2), October 2021

needs to start with teaching contents, teaching methods and teacher team. Therefore, teachers need to combine applied linguistics theory with practice in the classroom teaching process to cultivate social talents, which is also the purpose of language teaching in Egypt. Of course, on the basis of changing the teaching mode, better transferring knowledge to students and enabling them to learn and use it are the ultimate goal of language teaching.

\section{NOTES}

Continuous follow- up at every session is required for the success of the procedures.

\section{REFERENCES}

- Adams, C., \& Pierce, R. (1999). Characteristics of Effective Teaching. Language Teaching, 102, 107.

- Allen, M. (2004). Smart thinking. Oxford University Press.

- Boers, F. (1999). Learning vocabulary through metaphoric awareness. Études et Travaux, 3, 53-65.

- Cubukcu, F. (2008). Enhancing vocabulary development and reading comprehension through metacognitive strategies. Issues in Educational Research, 18(1), 1-11.

- Cruse, D.A. Lexical semantics. Cambridge, UK: Cambridge University Press.1986. 
- Davies, M. (2011). Concept mapping, mind mapping and argument mapping: what are the differences and do they matter?. Higher education, 62(3), 279-301.

- Deignan, A., Gabryś, D. \& Solska, A. (1997). Teaching English metaphors using cross-linguistic awareness-raising activities. ELT Journal, 51, 352-360. http://dx.doi.org/10.1093/elt/51.4.352

- Deignan, A., Gabryś, D., \& Solska, A. (1997). Teaching English metaphors using cross-linguistic awareness-raising activities. ELT journal, 51(4), 352-360.

- DOI: 10.4236/jss.2018.612029 347 Open Journal of Social Sciences

- Ellis, N. (1994a). Implicit and explicit language learning - An overview. In N. C. Ellis (Ed.), Implicit and explicit learning of languages (pp. 1-33). London, UK: Academic Press.

- English, M. I. Mastering Idiomatic English: Adjective Phrases. https://tesl-ej.org/ej15/r3.html Google Scholar

- Hollins, E. R. (2011). Teacher preparation for quality teaching. Journal of Teacher education, 62(4), 395-407.

- https://www.mindmeister.com/blog/mind-mapping-benefitswho-needs-mind-maps/

- Karpicke, J. D., \& Roediger III, H. L. (2007). Repeated retrieval during learning is the key to long-term retention. Journal of Memory and Language, 57(2), 151-162. 


\section{Educational and Psychological Studies Faculty of Education Journal Zagazig University Vol. (36) No. (113), Part(2), October 2021}

- Kern, R. G. (1994). The role of mental translation in second language reading. Studies in second language acquisition, 441-461

- Kömür, S. \& Çimen, S (2009). Using conceptual metaphors in teaching idioms in L2 context. Muğla Üniversitesi Sosyal Bilimler Enstitüsü Dergisi (İLKE) Güz, 205-221.

- Lakkis, K. \& Abdel Malak, M. Understanding the Transfer of Prepositions: Arabic to English. Bureau of Educational and Cultural Affairs: Office of English Language Programs.

Retrieved on 4/11/2011 http://eca.state.gov/forum/vols/vol38/no3/p26.htm

- Lazar, G. (1996). Using figurative language to expand students' vocabulary. ELT Journal, 50, 43-51. http://dx.doi.org/10.1093/elt/50.1.43

- Li, X. (2010). Conceptual metaphor theory and teaching of English and Chinese idioms. Journal of Language Teaching and Research, 1, 206-210. http://dx.doi.org/10.4304/jltr.1.3.206-210

- Liu, D. (2008). Idioms: Description, comprehension, acquisition, and pedagogy. New York/London: Routledge.

- Martin J Eppler1,( 2006)A comparison between concept maps, mind maps, conceptual diagrams, and visual behavior. Review of educational research, 51(4), 455-498.

- Naimushin, B., \& Stepanova, M. (2018). The Association of Translator and Interpreter Trainers: Building a Network of 
Teaching Excellence. Society and Languages in the Third Millenium. Communication. Education. Translation., 169-178.

- Samani, E. R. (2012). The effect of conceptual metaphors on learning idioms by 12 learners. International Journal of English Linguistics, 2(1), 249.

- Seamon, J. G., Lee, I. A., Toner, S. K., Wheeler, R. H., Goodkind, M. S., \& Birch, A. D. (2002). Thinking of critical words during study is unnecessary for false memory in the Deese, Roediger, and McDermott procedure. Psychological Science, 13(6), 526-531.

- Stight, T. G. (1979). Educational uses of metaphor. In A. Ortony (Ed.), Metaphor and thought (2nd ed., pp. 474-485). Cambridge: Cambridge University Press.

- Zhang, L. (2016). Error analysis of business English translation based upon functional theory. Advances in literary study, 4(3), 37-40. 